Article

\title{
Cyclic Gas Dissolution Foaming as an Approach for Simultaneously Reducing Cell Size and Relative Density in Nanocellular PMMA
}

\author{
Judith Martín-de León ${ }^{1, * \mathbb{D}}$, Victoria Bernardo ${ }^{2}$ and Miguel Ángel Rodriguez-Perez ${ }^{1,2}$ (D) \\ 1 Cellular Materials Laboratory (CellMat), Condensed Matter Physics Department, University of Valladolid, \\ 47011 Valladolid, Spain; marrod@fmc.uva.es \\ 2 CellMat Technologies S.L. Paseo de Belén 9A, 47011 Valladolid, Spain; v.bernardo@cellmattechnologies.com \\ * Correspondence: jmadeleon@fmc.uva.es
}

Citation: Martín-de León, J.;

Bernardo, V.; Rodriguez-Perez, M.Á.

Cyclic Gas Dissolution Foaming as an

Approach for Simultaneously

Reducing Cell Size and Relative

Density in Nanocellular PMMA.

Polymers 2021, 13, 2383. https://

doi.org/10.3390/polym13142383

Academic Editor: Emanoil Linul

Received: 15 June 2021

Accepted: 18 July 2021

Published: 20 July 2021

Publisher's Note: MDPI stays neutral with regard to jurisdictional claims in published maps and institutional affiliations.

Copyright: (c) 2021 by the authors. Licensee MDPI, Basel, Switzerland. This article is an open access article distributed under the terms and conditions of the Creative Commons Attribution (CC BY) license (https:// creativecommons.org/licenses/by/ $4.0 /)$.

\begin{abstract}
A new approach to produce nanocellular polymers combining small cell sizes with low relative densities is presented herein. This production method, based on gas dissolution foaming, consists of performing a double saturation and foaming cycle. Thus, nanocellular polymethylmethacrylate (PMMA) has been produced through a first saturation at different saturation conditions $(6,10$, and $20 \mathrm{MPa}$ and $\left.-32{ }^{\circ} \mathrm{C}\right)$, at constant foaming conditions $\left(60{ }^{\circ} \mathrm{C}\right.$ for $\left.1 \mathrm{~min}\right)$. Then, the nanocellular PMMAs obtained from the previous step were again saturated at different saturation conditions, $10 \mathrm{MPa} 24^{\circ} \mathrm{C}, 31 \mathrm{MPa} 24^{\circ} \mathrm{C}, 35 \mathrm{MPa} 22^{\circ} \mathrm{C}$, and $6 \mathrm{MPa}-15^{\circ} \mathrm{C}$ and foamed at different temperatures $\left(40,80\right.$ and $100^{\circ} \mathrm{C}$ ) for $1 \mathrm{~min}$. This new approach allows the cells created in the first saturation and foaming cycle to further grow in the second cycle. This fact permits producing nanocellular polymethylmethacrylate sheets combining, for the first time in the literature, cell sizes of $24 \mathrm{~nm}$ with relative densities of 0.3 .
\end{abstract}

Keywords: low-density nanocellular foam; gas dissolution foaming; PMMA; advanced cellular material

\section{Introduction}

Nanocellular materials have aroused great attention due to a combination of outstanding properties, such as low thermal conductivity, improved mechanical properties, the possibility of retaining solid polymer transparency after the foaming process, among others [1-4]. Industries such as the automotive one or the building sector could improve their current designs by using these materials. However, so as to take advantage of properties, such as the thermal insulation, it is mandatory to reduce the density of the cellular material in addition to the cell size [5-7].

Since their discovery, nanocellular materials have been produced using different polymers and through different approaches [1]. The most common production route is the gas dissolution foaming process using both homogeneous and heterogeneous nucleation mechanisms. Those efforts have led to the production of unique cellular structures $[4,8,9]$. However, previous studies have demonstrated that there are some limitations regarding the production of these materials. In fact, it is still difficult to produce materials with very small cell sizes and low relative densities $[1,10,11]$.

Polymethylmethacrylate (PMMA) is one of the most common polymers selected for the production of nanocellular polymers. This is due to its great affinity for $\mathrm{CO}_{2}$, leading to high solubilities $[10,12,13]$. According to the classical nucleation theory, maximization of the solubility leads to an increase in the number of nucleation points resulting in an easy way to produce cells in the nanometric range by using a homogeneous nucleation approach. Particularly for this polymer, some of the most promising values when the materials are produced by the homogeneous nucleation approach have been presented by Yeh et al. [14] with cell sizes of $37 \mathrm{~nm}$ combined with a relative density of 0.25 . However, the reported 
values were achieved for pellets and not for plates, and therefore the relative density values reported included the solid skin and the transition region with microcells and not only the nanocellular region (these two areas, skin and transition region, are difficult to remove in small pellets). Regarding nanocellular PMMA plates, the better values obtained through homogeneous nucleation have been presented by Martín-de León et al. with a cell size of $74 \mathrm{~nm}$ combined with a relative density of 0.24 , (values obtained in the nanocellular area of these samples) [15]. The use of a copolymer (PMMA-co-EMA) allowed Costeux et al. to produce materials with cell sizes of $80 \mathrm{~nm}$ with relative densities of 0.17 (values obtained considering skin and transition region) for this particular polymer [16-18]. Kumar et al. presented very interesting materials with relative densities of 0.3 and cell sizes of $50 \mathrm{~nm}$, or relative densities of 0.14 with cell sizes of $235 \mathrm{~nm}$, being the reported relative density values with solid skin and transition region [19].

Regarding heterogeneous nucleation, some interesting results have also been obtained. Pinto et al. produced nanocellular PMMA by adding MAM (block copolymer poly(methyl methacrylate)-poly(butyl acrylate)-poly(methyl methacrylate) with cell sizes around $250 \mathrm{~nm}$ and relative densities around 0.5 [20]. Bernardo et al. reported cell sizes from $200 \mathrm{~nm}$ to $300 \mathrm{~nm}$ and relative densities of the nanocellular region from 0.23 to 0.47 by adding MAM as nucleating agent [21]. Wang et al. presented cell sizes of $150 \mathrm{~nm}$ with 0.17 of relative density by using TPU as nucleating agent. In this case, the used samples present a cylindrical shape of $5 \mathrm{~mm}$ in diameter and $50 \mathrm{~mm}$ in length. Density measurements do not include solid skin but they do include the transition region contributing to reduction of the density values [22]. Costeux et al. reported values of $120 \mathrm{~nm}-0.15$, $99 \mathrm{~nm}-0.16$ and $65 \mathrm{~nm}-0.26$ of cell size-relative density (values including solid skin and transition region) using polyhedral oligomeric silsesquioxane (POSS) as the second phase. However, those works present the main drawback of the necessity of adding this second phase, leading to a more complex process [23].

On the other hand, when searching for the minimum cell size obtained with this polymer, the smaller values are presented by Martín-de León et al. [13]. In this work, cell sizes below $50 \mathrm{~nm}$ were reported with 39, 24, and $14 \mathrm{~nm}$ of cell size combined with relative densities of $0.38,0.43$, and 0.43 , respectively, values obtained after removing the skin and transition region.

In summary, plates of nanocellular materials with minimum cell sizes (smaller than $40 \mathrm{~nm}$ ) have never been reported to have densities below 0.4 . While the minimum relative densities reported around 0.15 correspond to materials with cell sizes not smaller than $120 \mathrm{~nm}$.

A new approach for producing nanocellular materials combining small cell sizes with low relative densities is proposed in the present work. This method proposes a cyclic gas dissolution foaming process allowing the production of materials not achievable using the common gas dissolution foaming process. Thus, nanocellular materials have been produced by means of a double saturation process leading to cell sizes as small as $24 \mathrm{~nm}$ (very close to the minimum value obtained so far) combined with relative densities of 0.3 , a combination of values never reported before.

The influence of the production parameters, for both the first and the second saturationfoaming cycles, on the final cellular structure has been analyzed.

\section{Materials and Methods}

\subsection{Materials}

Polymethylmethacrylate (PMMA) is the material used in this work. V825T grade has been supplied in the form of pellets from ALTUGLAS ${ }^{\circledR}$ International (Colombes, France).

The density of this material is $1.19 \mathrm{~g} / \mathrm{cm}^{3}$ (measured at $23{ }^{\circ} \mathrm{C}$ and $50 \% \mathrm{HR}$ ), its molecular weight measured through gel permeation chromatography is $\mathrm{M}_{\mathrm{n}}=43 \mathrm{~kg} / \mathrm{mol}$, and $\mathrm{M}_{\mathrm{w}}=83 \mathrm{~kg} / \mathrm{mol}$ and its glass transition temperature $\left(T_{g}\right)$ is $114{ }^{\circ} \mathrm{C}$ (measured through differential scanning calorimetry).

The used gas for the gas dissolution foaming experiments is $\mathrm{CO}_{2}$. 


\subsection{Samples Production}

\subsubsection{Precursors Production}

Solid sheets $4 \mathrm{~mm}$ in thickness have been compression molded through a cold/hot plate press (Remtex (Barcelona, Spain).

The as-received pellets were first dried overnight at $70{ }^{\circ} \mathrm{C}$ under vacuum. The dry pellets were introduced in a $4 \mathrm{~mm}$ thickness mold. The mold was first heated in the hot plates at $250{ }^{\circ} \mathrm{C}$ for $9 \mathrm{~min}$ without applying pressure. Afterward, a pressure of $42 \mathrm{MPa}$ was applied for one additional minute by keeping the temperature at $250{ }^{\circ} \mathrm{C}$. Finally, the material is cooled down in the cold plates at room temperature under the same pressure.

The obtained solid sheet is mechanized to $20 \times 20 \times 4 \mathrm{~mm}^{3}$ samples for the foaming experiments.

\subsubsection{Cellular Materials Production}

A cyclic process based on the gas dissolution foaming technique has been used for producing the nanocellular materials of this work [24].

Gas dissolution foaming comprises three steps: saturation, depressurization, and foaming. During saturation, the polymer is introduced in a pressure vessel under certain gas pressure and temperature, parameters known as saturation pressure $\left(P_{\text {sat }}\right)$ and saturation temperature $\left(T_{\text {sat }}\right)$. The gas, normally $\mathrm{CO}_{2}$, diffuses inside the polymer until the sample is fully saturated. The gas diffusion inside the polymer implies the reduction of the glass transition temperature $\left(T_{g}\right)$ down to the effective glass transition temperature $T_{g_{e f f}}$. After saturation time $\left(t_{s a t}\right)$, the gas is fast released in the depressurization step at a specific depressurization velocity $\left(v_{d e s}\right)$. This fast pressure drop results in a thermodynamic instability that creates nucleation points inside the polymer. Finally, in the foaming step, the polymer is introduced in a thermal bath at a foaming temperature $\left(T_{f}\right)$ higher than the effective glass transition temperature during the foaming time $\left(t_{f}\right)$. At these conditions, the nucleation points evolve into cells.

In this work, a cyclic process illustrated in Figure 1 is proposed. Once the cellular structure is produced and the $\mathrm{CO}_{2}$ of the first cycle has completely diffused out of the sample, a new gas dissolution foaming cycle is applied to the already foamed polymer. That means the produced nanocellular polymer in the first cycle is again saturated, depressurized, and foamed.

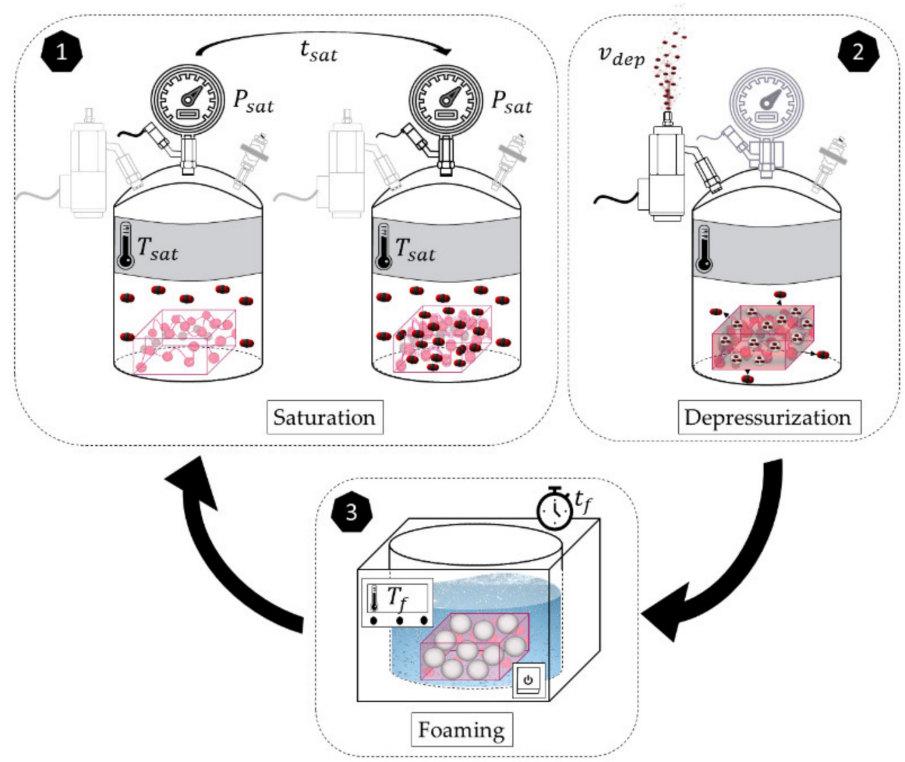

Figure 1. Scheme of the cyclic gas dissolution foaming process proposed in this work. 
The described experiments have been carried out in a pressure vessel (model PARR 4681) provided by Parr Instrument Company (Moline, IL, USA). The pressure is controlled through a pressure pump (model SFT-10) supplied by Supercritical Fluid Technologies Inc. (Newark, DE, USA). Additionally, a clamp heater connected to a temperature controller CAL 3000 is used to adjust the temperature of the system. Finally, an electrovalve with $\mathrm{K}_{\mathrm{v}}=1.1 \mathrm{~L} / \mathrm{min}$ allows fast release of the pressure.

A collection of experiments was performed to evaluate the effect of process conditions on the final cellular structure. The influence of the parameters in the first and second cycle is studied as it is detailed explained in Section 3.1.

\subsection{Characterization Techniques}

\subsubsection{Density}

The density of the solid materials $\left(\rho_{s}\right)$ has been measured through gas pycnometry (Mod. AccuPyc II 1340, Micromeritics, Norcross, GA, USA). The density of the cellular materials $\left(\rho_{f}\right)$ has been determined through a density determination kit of an AT261 Mettler-Toledo balance, considering the water displacement method, based on Archimedes' principle.

Relative density $\left(\rho_{r}\right)$ is defined as the fraction between the cellular material density and the solid one $\left(\rho_{r}=\rho_{f} / \rho_{s}\right)$. Cellular materials were polished, removing the solid skin and transition region before measuring the relative density. Polishing was done by means of a polisher model LaboPOl2-LaboForce 3 supplied by Struers. At least $200 \mu \mathrm{m}$ were removed on each side making sure to remove all the thickness comprising solid skin and transition region. Therefore, all the data reported in this paper correspond to the homogeneous nanocellular region of the samples.

\subsubsection{Solubility}

Solubility is defined as the percentage weight increase in the sample due to gas sorption. To determine solubility, the mass of the sample when it is fully saturated is needed. Since depressurization, the gas is diffusing out of the sample. To take this into account the mass loss vs. time was registered with a Mettler-Toledo balance. The mass of the sample when it is fully saturated is obtained by extrapolating to zero desorption time the measured mass [25].

\subsubsection{Scanning Electron Microscopy}

The cellular structure of each cellular material was examined through scanning electron microscopy (ESEM, Model QUANTA 200 FEG, Hillsboro, OR, USA). The area analyzed is in the inert part of the sample, i.e., far from the transition layer or skin.

Before the visualization, samples were fractured under liquid nitrogen to preserve the cellular structure as produced. Afterward, the visualization surface was coated with gold with a sputter coater (model SDC 005, Balzers Union, Balzers, Liechtenstein).

The obtained micrographs have been analyzed with a software-based on ImageJ/FIJI. Different parameters have been measured to characterize the cellular structure. Average cell size $(\phi)$ has been measured as the mean value of the average diameter of more than 200 cells per sample, cell nucleation density $\left(\mathrm{N}_{0}\right)$ was determined through Kumar's method [24]. Finally, the standard deviation of the cell size distribution divided by the average cell size $(S D / \phi)$ has been also evaluated.

\section{Results}

\subsection{Example of the Nanocellular Materials Obtained When a Double Cycle Is Carried Out}

The PMMA grade used in this study shows cellular structures as those shown in the bottom of Figure 2a. 


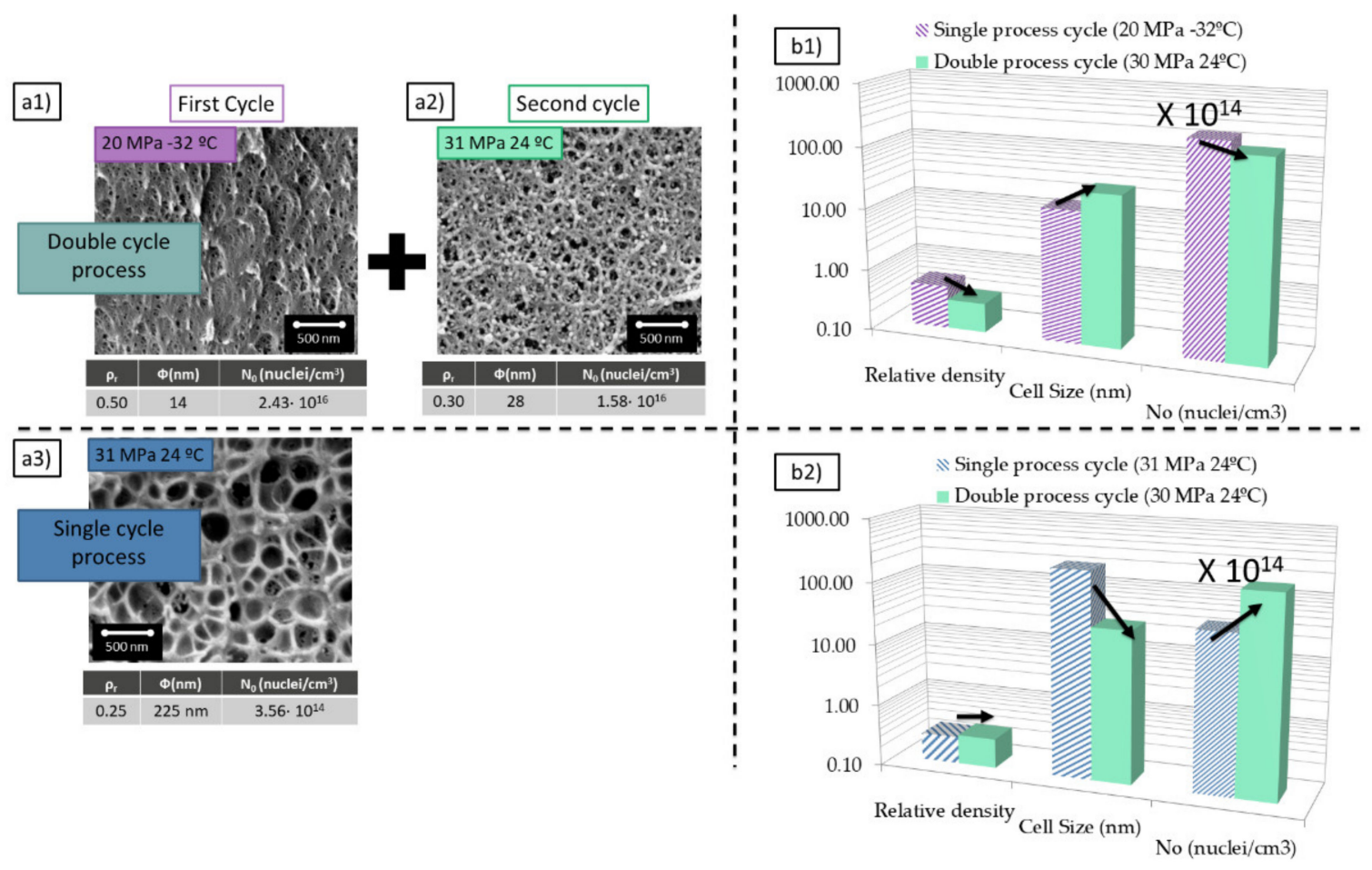

Figure 2. (a) Comparison between the cellular structures obtained after a first cycle at $20 \mathrm{MPa}-32{ }^{\circ} \mathrm{C}$ and foamed at $60{ }^{\circ} \mathrm{C}$ for $1 \mathrm{~min}(\mathbf{a} 1)$ and a second cycle at $31 \mathrm{MPa}, 24^{\circ} \mathrm{C}$ and foamed at $80^{\circ} \mathrm{C}$ for $1 \mathrm{~min}$ (a2) and the cellular structure obtained in a single cycle at saturation conditions of $31 \mathrm{MPa}$ and $24{ }^{\circ} \mathrm{C}$ with foaming at $100{ }^{\circ} \mathrm{C}$ for $1 \mathrm{~min}(\mathrm{a} 3)$. (b1) Comparison between relative density, cell size, and cell nucleation density between (a1) and (a2). (b2) Comparison between relative density, cell size, and cell nucleation density between (a3) and (a2).

This material presents cell sizes around $200 \mathrm{~nm}$ and relative densities of 0.25 when it is saturated at $31 \mathrm{MPa}$ and $24^{\circ} \mathrm{C}$ and foamed at $100^{\circ} \mathrm{C}$ for $1 \mathrm{~min}$. These conditions are the ones minimizing the density for this PMMA grade when cell sizes are in the range of $200 \mathrm{~nm}$. The cell nucleation density for these conditions is in the range of $3 \times 10^{14}$ cells $/ \mathrm{cm}^{3}$. The process parameters of this experiment are very the most appropriate to reach low densities at medium cell sizes.

On the other hand, when this material is saturated at $20 \mathrm{MPa}$ and $-32{ }^{\circ} \mathrm{C}$ presents cell sizes around $14 \mathrm{~nm}$ combined with a relative density of 0.5 (foaming at $60{ }^{\circ} \mathrm{C}$ for $1 \mathrm{~min}$ ) (Figure 2a1). Once again these are the optimum conditions to reduce the density when the cell size is in the range of $14 \mathrm{~nm}$. The cell nucleation density for these particular conditions is in the range of $2.4 \times 10^{16}$ cells $/ \mathrm{cm}^{3}$, i.e., two orders of magnitude higher than in the previous conditions. These process parameters minimize cell size but does not allow further reduction of density.

The introduction of a gas dissolution foaming consisting of two cycles that combine the two previous saturation cycles allows obtaining a cellular structure with a combination of characteristics that are not achieved through a single cycle process (Figure 2a3). Nanocellular PMMA with $28 \mathrm{~nm}$ of cell size and a relative density of 0.3 has been produced through a first saturation at $20 \mathrm{MPa}$ and $-32{ }^{\circ} \mathrm{C}$ and foaming at $60{ }^{\circ} \mathrm{C}$ for $1 \mathrm{~min}$ and a second saturation at $31 \mathrm{MPa}$ and $24{ }^{\circ} \mathrm{C}$ and foaming at $80^{\circ} \mathrm{C}$ for $1 \mathrm{~min}$ (Figure 2a2). For these conditions, the cell nucleation density is also very high, with values of $1.6 \times 10^{16} \mathrm{cells} / \mathrm{cm}^{3}$. Therefore, using this new approach, it has been possible to keep the cell nucleation density at very high values, but at the same time, it has been possible to reduce the relative density.

The structure obtained in the second cycle compared with the one obtained in the first one presents a significant reduction of the relative density from 0.5 to 0.3 while keeping the cell size and the cell nucleation density in the same order the magnitude (Figure 2b1). 
In comparison with the sample produced with similar conditions in just one cycle (31 MPa $24^{\circ} \mathrm{C}$ ), the introduction of a double cycle leads to a reduction of one order of magnitude in the cell size and an increase in two orders of magnitude in the cell nucleation density by almost keeping unchanged the relative density (Figure 2b2).

The achieved nanocellular material produced by the double cycle presents a unique combination of characteristics not reported up to now using a single cycle process.

Taking into account the previous promising result a set of experiments were carried out to study the influence of the saturation and foaming parameters on the final cellular structure. Firstly, the effect of the first cycle saturation parameters was studied by changing the saturation pressure while keeping constant the saturation parameters in the second cycle at $31 \mathrm{MPa}$ and $24^{\circ} \mathrm{C}$ (Figure 3a). Thus, saturation pressures of 6,10 , and $20 \mathrm{MPa}$ at a saturation temperature of $-32{ }^{\circ} \mathrm{C}$ were used in the first cycle. The foaming parameters of the second cycle have also been studied, changing the foaming temperature between 40 , 80 , and $100{ }^{\circ} \mathrm{C}$ with a foaming time of $1 \mathrm{~min}$.

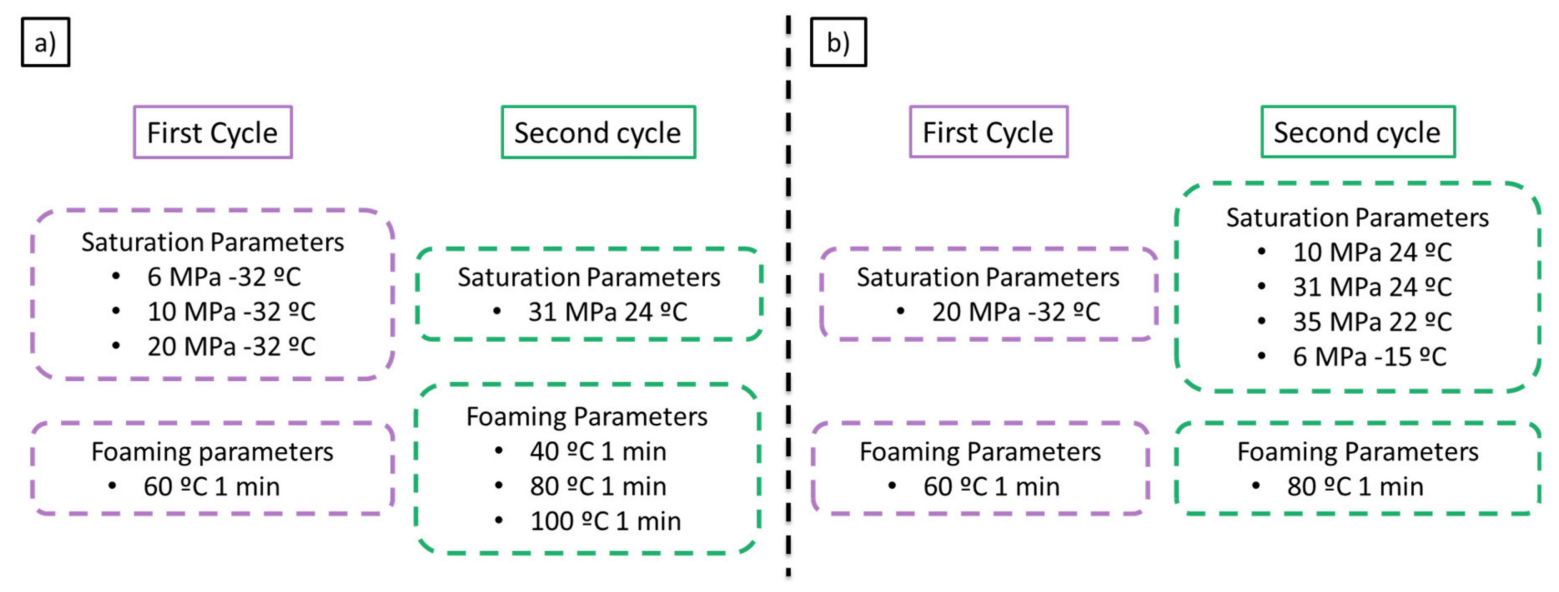

Figure 3. (a) Set of experiments to evaluate the effect of the first cycle saturation parameters and the effect of the second cycle foaming parameters on the final cellular structure. (b) Set of experiments carried out to evaluate the effect of the second cycle saturation parameters on the final cellular structure.

Secondly, the influence of the second cycle saturation parameters was studied while keeping constant the first cycle parameters in $20 \mathrm{MPa}$ and $-32{ }^{\circ} \mathrm{C}$ (Figure 3b). Saturation conditions allowing an increase in solubility in the second cycle were selected to be $10 \mathrm{MPa}$ and $24{ }^{\circ} \mathrm{C}, 31 \mathrm{MPa}$ and $24{ }^{\circ} \mathrm{C}, 35 \mathrm{MPa}$ and $22^{\circ} \mathrm{C}$, and $6 \mathrm{MPa}-15^{\circ} \mathrm{C}$. PMMA solubility at those conditions is $24.6 \mathrm{wt} . \%, 31.3 \mathrm{wt} . \%, 32.5 \mathrm{wt} . \%$, and $34.8 \mathrm{wt} . \%$, respectively.

The consequences for the cell size, cell nucleation density and relative density of all those modifications are detailed in the following sections.

\subsection{Influence of the Parameters of the First Cycle}

An increase in the saturation pressure in the first cycle leads to an increase in solubility in the material. Thus $6 \mathrm{MPa}$ leads to $38.6 \mathrm{wt} . \%$ of $\mathrm{CO}_{2}$ uptake, $10 \mathrm{MPa}$ to $41.0 \mathrm{wt} . \%$ and $20 \mathrm{MPa}$ to $45.5 \mathrm{wt} . \%$. As expected, smaller cell sizes and higher cell nucleation densities are obtained, as has been previously reported in the literature [15].

As shown in Figure 4, the cellular structures obtained after a second cycle performed at $31 \mathrm{MPa}$ and $24^{\circ} \mathrm{C}$ present a smaller cell size when the cell size of the starting cellular material obtained after the first cycle is also small. The results are similar for the cell nucleation density. The higher the cell nucleation density in the first cycle, the higher is the one obtained in the second one. The materials produced present interesting characteristics with a cell density over $10^{16}$ cells $/ \mathrm{cm}^{3}$ and low relative densities. 


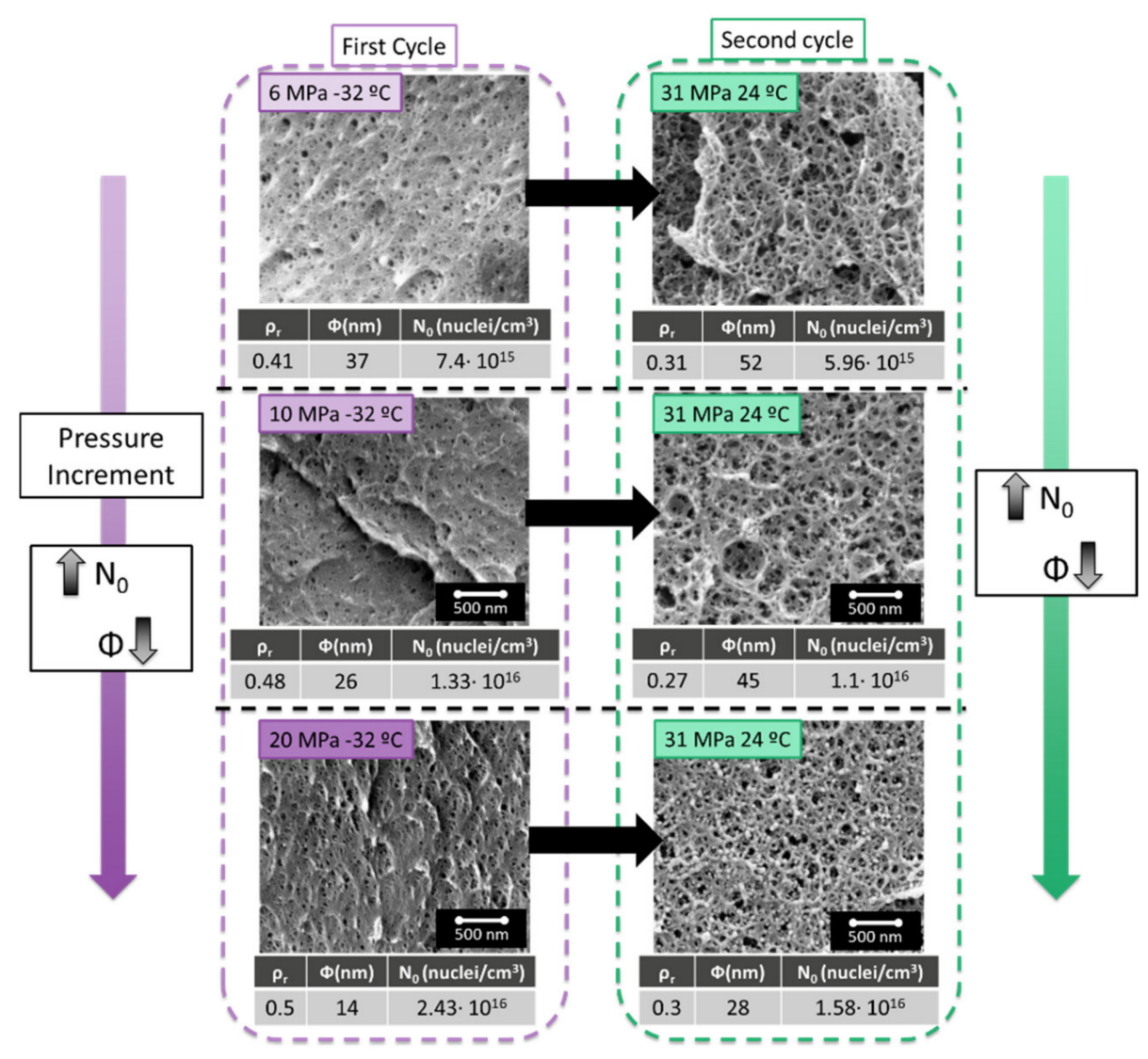

Figure 4. Effect of changing the first cycle parameters $\left(6 \mathrm{MPa}, 10 \mathrm{MPa}\right.$, and $20 \mathrm{MPa}$ and $-32{ }^{\circ} \mathrm{C}$ foamed at $60{ }^{\circ} \mathrm{C}$ during $1 \mathrm{~min}$ ) on the cellular structure obtained in the second cycle with the parameters fixed at $31 \mathrm{MPa}$ and $24^{\circ} \mathrm{C}$ and foamed at $80{ }^{\circ} \mathrm{C} 1 \mathrm{~min}$.

In conclusion, to minimize the cell size and maximize the cell nucleation density after the second cycle, the same should be done in the first cycle. Therefore, it is beneficial to maximize the solubility in the first cycle. On the other hand, the foaming parameters allowing a maximum cell nucleation densities in the first cycle were $60{ }^{\circ} \mathrm{C}$ and $1 \mathrm{~min}$ for $20 \mathrm{MPa}$ and $-32{ }^{\circ} \mathrm{C}$ of saturation pressure [13]. Those conditions have been therefore used in the next section of this paper.

Foaming temperatures in the second cycle have also been evaluated foaming at 40,80, and $100{ }^{\circ} \mathrm{C}$ for $1 \mathrm{~min}$. Table 1 shows this effect in samples with a fixed first cycle $(20 \mathrm{MPa}$ $-32{ }^{\circ} \mathrm{C}$ foamed at $60^{\circ} \mathrm{C}$ for $1 \mathrm{~min}$ ) and a second cycle performed at $31 \mathrm{MPa} 24^{\circ} \mathrm{C}$ and foaming at these three temperatures for $1 \mathrm{~min}$. As it can be seen relative densities were minimum through foaming at $80^{\circ} \mathrm{C}$, due to the maximization of the number of nucleation points at this temperature. Thus, for the following sections, these foaming conditions were fixed.

Table 1. Characteristics of nanocellular materials produced through a double cycle with different foaming temperatures in the second cycle. First cycle parameters $20 \mathrm{MPa}-32{ }^{\circ} \mathrm{C}$ foamed at $60{ }^{\circ} \mathrm{C}$ for $1 \mathrm{~min}$ and second cycle parameters $31 \mathrm{MPa} 24^{\circ} \mathrm{C}$.

\begin{tabular}{cccc}
\hline $\begin{array}{c}\text { Foaming Temperature } \\
\left({ }^{\circ} \mathbf{C}\right)\end{array}$ & Relative Density & $\begin{array}{c}\text { No } \\
\left(\mathbf{1} / \mathbf{c m}^{3}\right)\end{array}$ & $\begin{array}{c}\text { Cell Size } \\
(\mathbf{n m})\end{array}$ \\
\hline 40 & 0.49 & $9.22 \times 10^{15}$ & 23 \\
80 & 0.30 & $1.58 \times 10^{16}$ & 28 \\
100 & 0.41 & $1.05 \times 10^{16}$ & 27 \\
\hline
\end{tabular}


The results obtained in this section can be used to hypothesize about the foaming mechanisms taking place in this cycling gas dissolution foaming. As it is observed in the experimental results the cell nucleation density is almost kept when the second cycle is applied. As this second cycle has been carried out at conditions that typically provide cell nucleation densities in the range of $10^{14}$ cells $/ \mathrm{cm}^{3}$, the cells in the final materials should come from the first foaming step. Therefore, we can conclude that a very high number of cells is created in the first cycle, and then the second cycle is used mainly for growth of these cells, reducing the relative density.

\subsection{Influence of the Saturation Parameters of the Second Cycle}

Considering the information extracted from the previous section, the first cycle parameters have been fixed in $20 \mathrm{MPa}$ and $-32{ }^{\circ} \mathrm{C}$ as saturation parameters and $60{ }^{\circ} \mathrm{C}$ and $1 \mathrm{~min}$ as foaming parameters. These are the conditions giving the maximum cell nucleation density.

A second cycle of gas dissolution foaming was applied to this material using four different conditions, each of them leading to a higher solubility, as previously indicated.

As it can be seen in Figure 5, an increase in the solubility in the second cycle leads to a reduction in the cell size and an increase in the cell nucleation density.

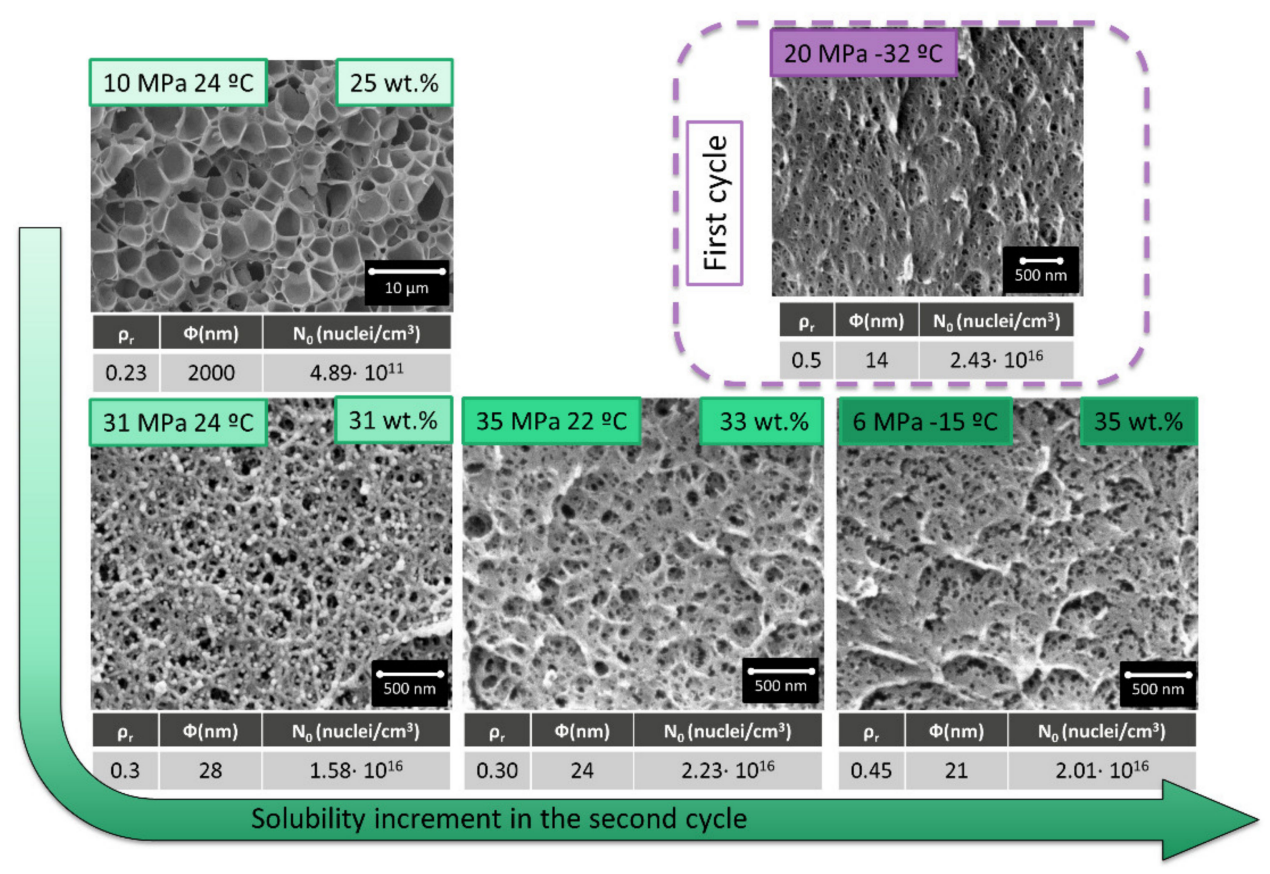

Figure 5. Cellular structures obtained at different saturation conditions in the second cycle (10 $\mathrm{MPa}$ $25^{\circ} \mathrm{C}, 30 \mathrm{MPa} 25^{\circ} \mathrm{C}, 35 \mathrm{MPa} 22^{\circ} \mathrm{C}$ and $6 \mathrm{MPa}-15^{\circ} \mathrm{C}$ and foamed at $80{ }^{\circ} \mathrm{C}$ for $1 \mathrm{~min}$ ) by fixing the saturation parameters in the first cycle at $20 \mathrm{MPa}$ and $-32{ }^{\circ} \mathrm{C}$ and foamed at $60^{\circ} \mathrm{C}$ for $1 \mathrm{~min}$.

Those results can be deeply analyzed by measuring the relative density, cell size, and cell nucleation density (Figure 6). The dashed line in Figure 6 indicates the values for a material produced in a single cycle at $20 \mathrm{MPa}-32{ }^{\circ} \mathrm{C}$, with a cell size of $14 \mathrm{~nm}$, a cell nucleation density of $2.43 \times 10^{16}$ nuclei $/ \mathrm{cm}^{3}$, and a relative density of 0.5 . As previously commented, those cell size values are the smallest reported in the literature for PMMA, with a relative density of 0.5 . 


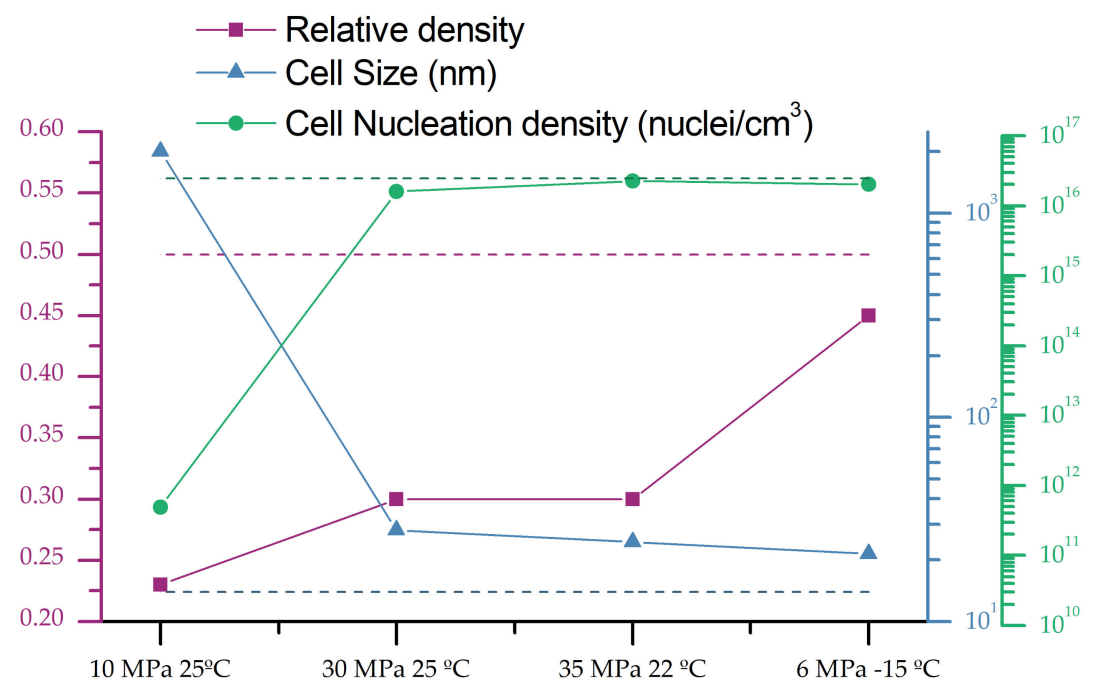

Figure 6. Relative density, cell size, and cell nucleation density of the samples produced with two cycles $\left(10 \mathrm{MPa} 25^{\circ} \mathrm{C}, 30 \mathrm{MPa} 25^{\circ} \mathrm{C}, 35 \mathrm{MPa} 22^{\circ} \mathrm{C}\right.$ and $6 \mathrm{MPa}-15^{\circ} \mathrm{C}$ and foamed at $80{ }^{\circ} \mathrm{C}$ for $1 \mathrm{~min}$ ) by fixing the saturation parameters in the first cycle at $20 \mathrm{MPa}$ and $-32{ }^{\circ} \mathrm{C}$ and foamed at $60{ }^{\circ} \mathrm{C}$ for $1 \mathrm{~min}$. The dotted line indicates the values obtained in a single cycle process at $20 \mathrm{MPa}$ and $-32{ }^{\circ} \mathrm{C}$ and foamed at $60^{\circ} \mathrm{C}$ for $1 \mathrm{~min}$.

Cellular structures presented after a second cycle have a decreasing cell size and an increasing cell nucleation density as solubility rises. However, the most remarkable factor is the obtained relative density, which is always smaller than the one presented for the initial material.

Poor solubility in the second cycle of $25 \mathrm{wt} . \%$ (obtained at $10 \mathrm{MPa}$ and $24{ }^{\circ} \mathrm{C}$ ) leads to cells bigger than the micron, while the most extreme conditions of $6 \mathrm{MPa}$ and $-15^{\circ} \mathrm{C}$ ( $35 \mathrm{wt} . \%$ of gas uptake) leads to a cellular structure very similar in density and with a larger cell size than the initial one. The most remarkable cellular structures are those obtained at intermediate saturation conditions. Saturation parameters of $30 \mathrm{MPa} 24^{\circ} \mathrm{C}$ and $35 \mathrm{MPa}$ $22^{\circ} \mathrm{C}$, leads to cell sizes clearly below $50 \mathrm{~nm}$ and cell nucleation densities that are almost as high as that of the material obtained in the first cycle. However, the relative density of those materials is much smaller (0.3), being this combination of cellular structure parameters unique in the previous literature when only the nanocellular structure is analyzed.

The obtained results can be explained as follows: in the first cycle, a high amount of small cells are created, while in the second cycle, those cells are preferential sites to either nucleate or further grow due to the pre-existing cell decrease the energy barrier for both processes. That means in this process, it can be assumed that nucleation occurs in the first cycle and those cells can further growth in the second one if the conditions are favorable. When saturation parameters are as soft as $10 \mathrm{MPa} 24^{\circ} \mathrm{C}$, the solubility is so small that the energy is not enough to take advantage of the previous nucleation points leading to microcellular structures. However, for both intermediate saturation conditions, $14 \mathrm{~nm}$ cells act as nucleation points that are further growth. When comparing the cell nucleation densities in the second and in the first cycle, $92 \%$ of the nuclei in the first cycle are able to grow in the second one. The initial $14 \mathrm{~nm}$ cells grow up to $24 \mathrm{~nm}$ leading to the observed reduction in the relative density.

Saturation conditions of $6 \mathrm{MPa}$ and $-15^{\circ} \mathrm{C}$ lead to such high solubility that the effect is not so notable, although the mechanisms seem to remain the same. All the nucleation points are used, and slightly further growth occurs. The cell size is kept in minimal values, and the reduction in relative density is not so large. 


\subsection{Single Cycle Process vs. Double Cycle Process}

In previous sections, the materials obtained with a double cycle process were compared with the ones obtained in the first cycle.

This last section is dedicated to comparing the materials obtained through a double cycle with samples produced in a single cycle process with the same production conditions of the second cycle of the double cycle samples. That means that a sample produced through a double saturation, first one at $20 \mathrm{MPa}-32{ }^{\circ} \mathrm{C}$ and second one at $35 \mathrm{MPa} 22^{\circ} \mathrm{C}$, will be compared with a sample produced through a single saturation at $35 \mathrm{MPa}$ and $22^{\circ} \mathrm{C}$.

As is shown in Figure 7, a double cycle process results in smaller cell sizes and higher cell nucleation densities. This confirms the heterogeneous nucleation theory proposed in the previous section.

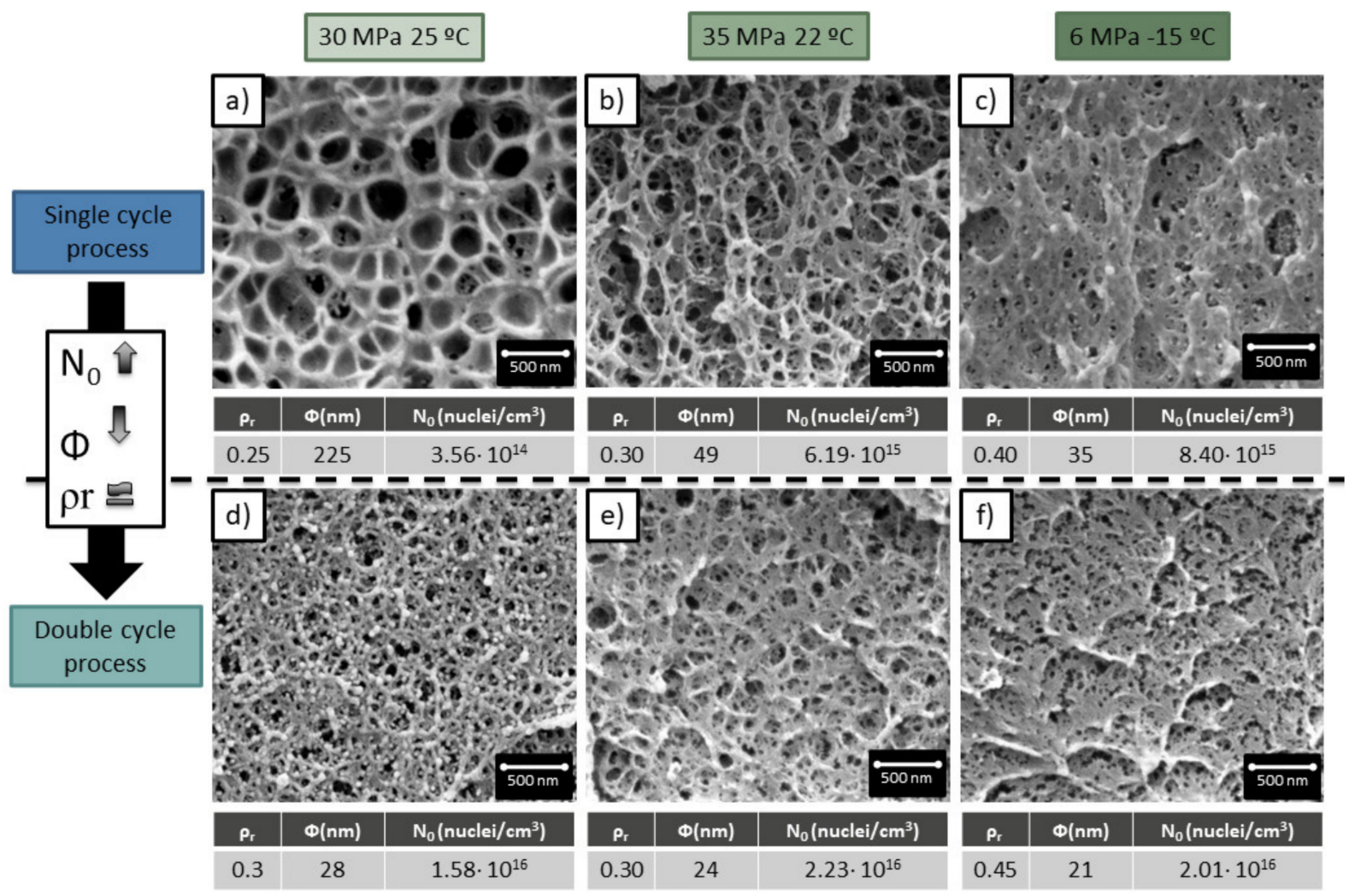

Figure 7. Comparison between the cellular structures obtained in a single cycle process $(\mathbf{a}-\mathbf{c})$ and a double cycle process (d-f). The single cycle process was carried out at $31 \mathrm{MPa} 24^{\circ} \mathrm{C}, 35 \mathrm{MPa} 22^{\circ} \mathrm{C}, 6 \mathrm{MPa}-15^{\circ} \mathrm{C}$. The double cycle process is carried out at the same conditions during the first cycle and at $20 \mathrm{MPa}-32{ }^{\circ} \mathrm{C}$ foamed at $60^{\circ} \mathrm{C}$ for $1 \mathrm{~min}$ for the second cycle.

Although the cell sizes have been strongly reduced with respect to the single cycle process, the significant increment of cell nucleation density, the low relative density is almost maintained.

Therefore, it can be concluded that the newly proposed method leads to cellular materials with characteristics not achievable through the common gas dissolution process. The double cycle process allows producing cell sizes of $24 \mathrm{~nm}$ with relative densities of 0.3 , being the minimum density reported in the literature of 0.43 for such cell sizes and cell nucleation densities of $2 \times 10^{16}$ cells $/ \mathrm{cm}^{3}$.

\section{Conclusions}

A double cycle gas dissolution foaming process is proposed in this work for the production of nanocellular PMMA. This process consists of a double saturation and foaming 
process. The PMMA is firstly saturated and foamed at certain conditions. The obtained nanocellular material is again saturated and foamed.

The influence of the production parameters has been studied. To minimize the cell size of the final material, it has been demonstrated that the cell size should also be minimum in the first cycle. A minimum cell size is reached through a maximum solubility; thus, $20 \mathrm{MPa}$ and $-32{ }^{\circ} \mathrm{C}$ were selected as the optimum saturation parameters in this work for the first cycle. The foaming parameters in the first cycle have been chosen to be $60^{\circ} \mathrm{C}$ and $1 \mathrm{~min}$ to maximize the cell nucleation density.

Introducing a second cycle could lead to further growth of the cells created in the first cycle. The influence of the second cycle parameters has been studied, proving that there exists an optimum range of saturation parameters in the second cycle. Thus, a saturation pressure of $35 \mathrm{MPa}$ and a saturation temperature of $22{ }^{\circ} \mathrm{C}$ leads to the production of nanocellular PMMA, combining a cell size of $24 \mathrm{~nm}$ with a relative density of 0.3 . Those values have not been reached through a single gas dissolution foaming process for materials produced with the shape of a plate in which the skin and transition layer have been removed, herein presented for the first time.

Author Contributions: Conceptualization, J.M.-d.L. and M.Á.R.-P.; methodology, J.M.-d.L. and V.B.; software, J.M.-d.L.; validation, J.M.-d.L., V.B. and M.Á.R.-P.; formal analysis, J.M.-d.L.; investigation, J.M.-d.L.; resources, M.Á.R.-P.; data curation, J.M.-d.L.; writing—original draft preparation, J.M.-d.L.; writing—review and editing, J.M.-d.L., M.Á.R.-P. and V.B.; supervision, M.Á.R.-P.; project administration, M.Á.R.-P.; funding acquisition, M.Á.R.-P. and V.B. All authors have read and agreed to the published version of the manuscript.

Funding: This research was funded by Junta of Castile and Leon, grant number VA202P20, Spanish Ministry of Science, Innovation, and Universities (RTI2018-098749-B-I00 and PTQ2019-010560 (Victoria Bernardo-García) and the "Ente Público Regional de la Energía de Castilla y León" (EREN).

Institutional Review Board Statement: Not applicable.

Informed Consent Statement: Not applicable.

Conflicts of Interest: The authors declare no conflict of interest. The funders had no role in the design of the study; in the collection, analyses, or interpretation of data; in the writing of the manuscript, or in the decision to publish the results.

\section{References}

1. Martín-de León, J.; Bernardo, V.; Rodríguez-Pérez, M.Á. Nanocellular polymers: The challenge of creating cells in the nanoscale. Materials 2019, 12, 797. [CrossRef] [PubMed]

2. Martín-de León, J.; Pura, J.L.; Bernardo, V.; Rodríguez-Pérez, M.Á. Transparent nanocellular PMMA: Characterization and modeling of the optical properties. Polymer 2019, 170, 16-23. [CrossRef]

3. Miller, D.; Kumar, V. Microcellular and nanocellular solid-state polyetherimide (PEI) foams using sub-critical carbon dioxide II. Tensile and impact properties. Polymer 2011, 52, 2910-2919. [CrossRef]

4. Guo, H.; Kumar, V. Some thermodynamic and kinetic low-temperature properties of the $\mathrm{PC}-\mathrm{CO}_{2}$ system and morphological characteristics of solid-state PC nanofoams produced with liquid $\mathrm{CO}_{2}$. Polymer 2015, 56, 46-56. [CrossRef]

5. Bernardo, V.; Martin-de Leon, J.; Pinto, J.; Verdejo, R.; Rodriguez-Perez, M.A. Modeling the heat transfer by conduction of nanocellular polymers with bimodal cellular structures. Polymer 2019, 160, 126-137. [CrossRef]

6. Notario, B.; Pinto, J.; Solorzano, E.; De Saja, J.A.; Dumon, M.; Rodriguez-Perez, M.A. Experimental validation of the Knudsen effect in nanocellular polymeric foams. Polymer 2015, 56, 57-67. [CrossRef]

7. Ferkl, P.; Pokorný, R.; Bobák, M.; Kosek, J. Heat transfer in one-dimensional micro- and nano-cellular foams. Chem. Eng. Sci. 2013, 97, 50-58. [CrossRef]

8. Bernardo, V.; Martín-De León, J.; Rodríguez-Pérez, M.A. Production and characterization of nanocellular polyphenylsulfone foams. Mater. Lett. 2016, 178, 155-158. [CrossRef]

9. Zhou, C.; Sundarram, S.S.; Li, W.; Vaccaro, N.; Zhou, C.; Vaccaro, N.; Sundarram, S.S.; Li, W. Fabrication and Characterization of Polyetherimide Nanofoams using Supercritical $\mathrm{CO}_{2}$. J. Cell. Plast. 2012, 48, 239-255. [CrossRef]

10. Costeux, S. $\mathrm{CO}_{2}$-blown nanocellular foams. J. Appl. Polym. Sci. 2014, 131. [CrossRef]

11. Okolieocha, C.; Raps, D.; Subramaniam, K.; Altstädt, V. Microcellular to nanocellular polymer foams: Progress (2004-2015) and future directions-A review. Eur. Polym. J. 2015, 73, 500-519. [CrossRef] 
12. Tomasko, D.L.; Li, H.B.; Liu, D.H.; Han, X.M.; Wingert, M.J.; Lee, L.J.; Koelling, K.W. A review of $\mathrm{CO}_{2}$ applications in the processing of polymers. Ind. Eng. Chem. Res. 2003, 42, 6431-6456. [CrossRef]

13. Martin-de Leon, J.; Bernardo, V.; Rodriguez-Perez, M.A. Key Production Parameters to Obtain Transparent Nanocellular PMMA. Macromol. Mater. Eng. 2017, 302, 1700343. [CrossRef]

14. Yeh, S.K.; Liao, Z.E.; Wang, K.C.; Ho, Y.T.; Kurniawan, V.; Tseng, P.C.; Tseng, T.W. Effect of molecular weight to the structure of nanocellular foams: Phase separation approach. Polymer 2020, 191, 122275. [CrossRef]

15. Martín-de Leon, J.; Bernardo, V.; Laguna-gutiérrez, E.; Rodríguez-pérez, M.Á. Influence of the viscosity of PMMA on the cellular structure of nanocellular materials. Polym. Int. 2020, 69, 72-83. [CrossRef]

16. Costeux, S.; Bunker, S.P. Homogeneous nanocellular foams from styrenic-acrylic polymer blends. J. Mater. Res. 2013, 17, 2351. [CrossRef]

17. Costeux, S.; Khan, I.; Bunker, S.P.; Jeon, H.K. Experimental study and modeling of nanofoams formation from single phase acrylic copolymers. J. Cell. Plast. 2015, 51, 197-221. [CrossRef]

18. Costeux, S.; Jeon, M.H.; Bunker, T.S.; Khan, I. Nanocellular foams from acrylic polymers experiments and modeling. In Proceedings of the FOAMS 2012 Conference, Barcelona, Spain, 12-13 September 2012; pp. 1-6.

19. Guo, H.; Nicolae, A.; Kumar, V. Solid-state poly(methyl methacrylate) (PMMA) nanofoams. Part II: Low-temperature solid-state process space using $\mathrm{CO}_{2}$ and the resulting morphologies. Polymer 2015, 70, 231-241. [CrossRef]

20. Pinto, J.; Dumon, M.; Pedros, M.; Reglero, J.; Rodriguez-Perez, M.A. Nanocellular $\mathrm{CO}_{2}$ foaming of PMMA assisted by block copolymer nanostructuration. Chem. Eng. J. 2014, 243, 428-435. [CrossRef]

21. Bernardo, V.; Martin-de Leon, J.; Pinto, J.; Catelani, T.; Athanassiou, A.; Rodriguez-Perez, M.A. Low-density PMMA/MAM nanocellular polymers using low MAM contents: Production and characterization. Polymer 2019, 163, 115-124. [CrossRef]

22. Wang, G.; Zhao, J.; Mark, L.H.; Wang, G.; Yu, K.; Wang, C.; Park, C.B.; Zhao, G. Ultra-tough and super thermal-insulation nanocellular PMMA/TPU. Chem. Eng. J. 2017, 325, 632-646. [CrossRef]

23. Costeux, S.; Zhu, L. Low density thermoplastic nanofoams nucleated by nanoparticles. Polymer 2013, 54, 2785-2795. [CrossRef]

24. Kumar, V.; Suh, N.P. A process for making microcellular thermoplastic parts. Polym. Eng. Sci. 1990, 30, 1323-1329. [CrossRef]

25. Fanovich, M.A.; Jaeger, P. Sorption and diffusion of compressed carbon dioxide in polycaprolactone for the development of porous scaffolds. Mater. Sci. Eng. C 2012, 32, 961-968. [CrossRef] 